\title{
DISTRIBUTION OF VIRULENCE MARKERS IN CLINICAL AND ENVIRONMENTAL Vibrio cholerae NON-01/NON-0139 STRAINS ISOLATED IN BRAZIL FROM 1991 TO 2000
}

\author{
Grace Nazareth Diogo THEOPHILO(1), Dália dos Prazeres RODRIGUES(1), Nilma Cintra LEAL(2) \& Ernesto HOFER(1)
}

\begin{abstract}
SUMMARY
One hundred seventy nine Vibrio cholerae non-O1/non-O139 strains from clinical and different environmental sources isolated in Brazil from 1991 to 2000 were serogrouped and screened for the presence of four different virulence factors. The Random Amplification of Polymorphic DNA (RAPD) technique was used to evaluate the genetic relatedness among strains. Fifty-four different serogroups were identified and V. cholerae O26 was the most common (7.8\%). PCR analysis for three genes (ctxA, zot, ace) located of the CTX genetic element and one gene (tcpA) located on the VPI pathogenicity island showed that 27 strains harbored one or more of these genes. Eight (4.5\%) strains possessed the complete set of CTX element genes and all but one of these belonged to the $\mathrm{O} 26$ serogroup suggesting that $V$. cholerae $\mathrm{O} 26$ has the potential to be an epidemic strain. The RAPD profiles revealed a wide variability among strains and no genetic correlation was observed.
\end{abstract}

KEYWORDS: Vibrio cholerae O26; CTX; Virulence genes; Genotypic variation; Epidemic potential.

\section{INTRODUCTION}

$V$. cholerae, a Gram-negative bacterium is the causative agent of cholera. The conventional method used to classify $V$. cholerae strains is a serotyping scheme based on epitopic variation cell surface lipopolysaccharide (LPS). Up to now, there is near 200 serogroups $^{37}$ and two serotypes (Inaba e Ogawa) identified for serogroup O1. The specie has been divided into serogroups $\mathrm{O} 1$ and non-O1 which differ each other for their ability to cause cholera epidemics ${ }^{7}$. Prior to 1992, it was believed that only $V$. cholerae $\mathrm{O} 1$ strains were responsible for pandemics of cholera and all major epidemics ${ }^{16}$, and the non-O1 strains were non virulent responsible for sporadic cases of gastroenteritis ${ }^{26}$ and extra-intestinal infections ${ }^{24}$. In 1992, an outbreak of cholera in India and Bangladesh, which subsequently spread into several parts of the subcontinent, was caused by a novel non-O1 strain: V. cholerae O139 Bengal $^{1}$.

V. cholerae $\mathrm{O} 1$ produces cholera toxin $(\mathrm{CT})$ which is responsible for secretory diarrhea and is encoded by the $\operatorname{ctx} \mathrm{A}$ and $\operatorname{ct} x \mathrm{~B}$ genes. Although CT is responsible for disease, the search for additional enterotoxins produced by $V$. cholerae, which has included volunteer studies of genetically engineered $c t x$-deleted $V$. cholerae, has led to discovery of new toxins ${ }^{15}$. The zonula occludens toxin (ZOT) acts on intestinal tight junctions to increase intestinal permeability ${ }^{3,18,20}$. The accessory cholera enterotoxin (ACE) increases potential difference across intestinal epithelium and alters ion transport ${ }^{20}$. The $\operatorname{ctx} \mathrm{A}, \operatorname{ct} x \mathrm{~B}$, zot and, ace genes are located on the CTX genetic element, which is composed of a 4.5-Kb central region termed the core region or virulence cassette $^{30}$. The CTX genetic element, a filamentous bacteriophage that infects $V$. cholerae and its close relative $V$. mimicus ${ }^{4,12}$ is present on the chromosome of toxigenic strains and absent in non-toxigenic strains ${ }^{22}$, but $V$. cholerae pathogenicity depends on a combination of factors as ability to produce a cholera toxin (CT) and to adhere and colonize the small intestine through colonization factor known as toxin-coregulated pilus (TCP). It had been accepted that CT and TCP were exclusively associated with clinical strains of $V$. cholerae, notably those belonging to serogroups $\mathrm{O} 1$ and $\mathrm{O} 139$, whereas reports on the incidence of CT among environmental strains are rare $^{6}$. Similarly, TCP had rarely been reported among environmental strains of $V$. cholerae, suggesting that TCP is associated only with virulent $V$. cholerae $\mathrm{O} 1$ or $\mathrm{O} 139$ strains. However, in the last years, the presence of $c t x \mathrm{AB}$ and tcp $\mathrm{A}$ genes in non-O1/non-O139 toxigenic and non-toxigenic strains has been observed $^{31}$.

In the present study, PCR was used to detect the presence of $c t x \mathrm{~A}$, zot, ace, and tcpA genes on $179 \mathrm{~V}$. cholerae strains. We also used RAPDPCR to evaluate the genetic relatedness among some clinical and environmental $V$. cholerae non-O1/non-O139 strains.

\section{MATERIALS AND METHODS}

Bacterial strains: A total of 179 V. cholerae non-O1/non-O139 strains isolated from faeces of suspected cholera patients (139 strains) and from environmental (40 strains from water of different ecosystems) 


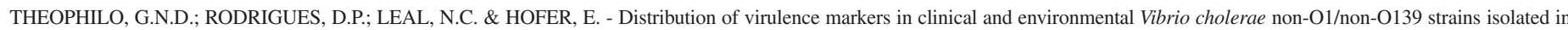
Brazil from 1991 to 2000. Rev. Inst. Med. trop. S. Paulo, 48(2):65-70, 2006.

Table 1

Primers sequences used for detection of virulence genes by PCR

\begin{tabular}{|c|c|c|c|}
\hline Gene & Primer sequence $\left(5^{\prime}-3^{\prime}\right)$ & Size (bp) & Reference \\
\hline $\operatorname{ctx} \mathrm{A}$ & CTCAGACGGGATTTGTTAGGCACGTCTATCTCTGTAGCCCCTATTACG & 301 & 19 \\
\hline zot & GCTATCGATATGCTGTCTCCTCAAAAAGCCGACCAATACAAAAACCAA & 900 & 21 \\
\hline ace & AGAGCGCTGCATTTATCCTTATTGAACTCGGTCTCGGCCTCTCGTATC & 600 & 21 \\
\hline$t c p \mathrm{~A}_{\mathrm{ET}}$ & GAAGAAGTTTGTAAAAGAAGAACACGAAAGGACCTTCTTTCACGTTG & 471 & 19 \\
\hline
\end{tabular}

were selected for this study. These strains were isolated during 1991 to 2000 and belonged to the collection of National Reference Laboratory for Cholera and Enteric Diseases at Oswaldo Cruz Institute (Fiocruz/ RJ). Clinical strain V. cholerae O1, classical biotype (569B) and one environment strain $V$. cholerae non-O1/non-O139 (E8498, provided by R. R. Colwell, University of Maryland, USA); the ctxA, zot, ace, and tcpA genes and absent and present on these two strains, respectively, and were used as controls.

Isolation and identification of $V$. cholerae strains were performed according to the guidelines from the Brazilian Health Ministry ${ }^{23}$.

The strains that did not agglutinate with either $\mathrm{O} 1$ or $\mathrm{O} 139$ antisera were considered non-O1/non-O139. They were sent to the National Institute of Health, Tokyo, Japan for serogroup identification.

PCR assay: A PCR - based assay was used to determine the presence of $c t x \mathrm{~A}$, zot, ace, and tcp A genes in individual strains ${ }^{29}$. The primers used for this assay and the expected amplicon sizes for each gene are listed in Table 1 . The following were added to each $25 \mu \mathrm{L}$ of PCR mixture: $2.5 \mu \mathrm{L}$ of $10 x$ PCR buffer $\left(500 \mathrm{mM} \mathrm{KCl}, 15 \mathrm{mM} \mathrm{MgCl}_{2}\right.$, $100 \mathrm{mM}$ Tris-HCl [pH 9.0]); $2 \mu \mathrm{L}$ of the $160 \mu \mathrm{M}$ dNTP mix (dATP, dTTP, dGTP, dCTP); $1 \mu \mathrm{L}$ (20 pmol) each of the primer; $0.2 \mu \mathrm{L}(1 \mathrm{U})$ of Taq DNA polymerase (Amersham Pharmacia) and $17.3 \mu \mathrm{L}$ of doubledistilled water. PCR was carried out in $0.5 \mathrm{~mL}$ microcentrifuge tubes with $24 \mu \mathrm{L}$ of the PCR mixture described above and $1 \mu \mathrm{L}$ of template. Whole-cell suspensions were used as template for all PCRs. Cells were harvested from overnight growth on nutrient agar (Oxoid), transferred into $500 \mu \mathrm{L}$ of water and vortexed to homogeneity. Suspensions were boiled at $100{ }^{\circ} \mathrm{C}$ for $20 \mathrm{~min}$ and then stored at $-20^{\circ} \mathrm{C}$. The solution was overlaid with a drop of sterile mineral oil (Sigma), and PCR was performed in an automated thermocycler (Perkin Elmer). The PCR reaction was performed on 30 cycles: $95^{\circ} \mathrm{C}$ for one min, $60{ }^{\circ} \mathrm{C}$ for one min, $72{ }^{\circ} \mathrm{C}$ for $1.5 \mathrm{~min}$, and then kept at $72{ }^{\circ} \mathrm{C}$ for seven min. A nontemplate control and the strains 569B and E8498 were included in each run as negative and positive controls for the absence/presence of ctxA, zot, ace, and tcpA genes, respectively. Presence of PCR product was visualized on $1 \%$ agarose gels after stained with ethidium bromide. A 100 base-pair molecular size ladder (Amersham Pharmacia) was included in each gel.

RAPD-PCR: In order to evaluate the genomic relatedness among clinical and environmental $V$. cholerae non-O1/non-O139 strains, 26 $V$. cholerae non-O1/non-O139 strains that hosted any virulenceassociated gene and 12 non-virulent strains were selected for RAPDPCR (Table 3).

Genomic DNA was extracted following the procedure described
Table 2

Distribution of Vibrio cholerae non-O1/non-O139 serogroups isolated from different sources

\begin{tabular}{lc}
\hline Serogroup (Sources)* & $\begin{array}{c}\text { Number of strains } \\
\text { belonging to each } \\
\text { serogroup }\end{array}$ \\
\hline O2(H), O12(H), O21(H), O22(H), O27(H), & 1 \\
O31(H), O33(E), O41(E), O43(H), O48(H), \\
O49(H), O52(H), O53(E), O99(E), O100(E), \\
O103(H), O141(H), O151(E),O195(E), O203(E) \\
O5(H), O14(H), O18(H), O19(H/E), O23(H), \\
O32(H), O40(H/E), O56(H), O97(H), O101(E), \\
O119(H) \\
O7(H), O13(H/E), O39(H/E), O51(H/E), O64(H), \\
O69(H), O74(H), O94(H), O110(H/E) \\
O17(H), O28(H/E), O45(H), O68(H/E), O112(E) \\
O62(H/E) \\
O11(H) \\
O8(H), O36(H/E) \\
O6(H/E) & 3 \\
O10(H), O34(H/E) & 6 \\
O37(H/E) & 7 \\
O26(H/E) & 179 \\
O UK (H) & 8 \\
\hline TOTAL & 12 \\
\hline
\end{tabular}

Sources*: $(\mathrm{H})=$ Human, $(\mathrm{E})=$ Environment, $(\mathrm{H} / \mathrm{E})=$ Human and environment, O UK = Unknown serogroup - not typable.

by AUSUBEL et al. ${ }^{2}$. Preliminary assays were performed with $V$. cholerae and sixteen 10-nucleotide random primers drawn for different purposes (784: 5'-GCGGAAATAG-3'; 785: 5'-CCGCAGCCAA-3'; 786: 5'-GCGATCCCCA-3'; 787: 5'-AACGCGCAAG-3'; 788: 5'GTGGATGCGA-3'; 789: 5'-AGCCAGTTTA-3'; 790: 5'GTCAACGAAG-3'; 791: 5'-GAGGACAAAG-3'; 792: 5'GGTACTCCCA-3'; 793: 5'-GACCGACCCA-3'; 794: 5'ACTGAACGCA-3'; 795: 5'-GAGACGCACA-3'; 796: 5'ACCTCAGCTG-3'; 797: 5'-AGCGTCACTG-3'; 798: 5'TGACCCGCCG-3'; 799: 5'-GGCTTGGCCG-3') to select the primers that generated clear and reproducible bands. The primers 784, 785 and 791 were found to be the most appropriate. Amplification reactions 
Table 3

Characteristics of Vibrio cholerae non-O1/non-O139 serogroups analyzed by RAPD-PCR

\begin{tabular}{|c|c|c|c|}
\hline $\begin{array}{l}\text { Isolate } \\
\text { No. IOC }\end{array}$ & Serogroup & Source & $\begin{array}{l}\text { Presence of } \\
\text { analyzed genes }\end{array}$ \\
\hline $157,3874,3905$ & O6 & Human & zot \\
\hline 13153 & $\mathrm{O} 7$ & Human & zot, ace \\
\hline 1614 & $\mathrm{O} 7$ & Human & - - \\
\hline 14721 & O8 & Human & —- \\
\hline 4005 & $\mathrm{O} 10$ & Human & zot \\
\hline 15251,15380 & $\mathrm{O} 10$ & Human & - - \\
\hline 13165 & $\mathrm{O} 14$ & Human & - - \\
\hline 2556 & $\mathrm{O} 17$ & Human & zot, ace \\
\hline 3647,16352 & $\mathrm{O} 26$ & Human & $z o t$ \\
\hline 1717,10626 & $\mathrm{O} 26$ & Human & zot, ace \\
\hline $\begin{array}{l}11043,13663, \\
15677\end{array}$ & $\mathrm{O} 26$ & Human & zot, ace tcp $\mathrm{A}$ \\
\hline $\begin{array}{l}3340,4756 \\
6958,11159\end{array}$ & & & \\
\hline 13151 & $\mathrm{O} 26$ & Human & $\operatorname{ctx} \mathrm{A}$, zot, ace \\
\hline 4010 & $\mathrm{O} 26$ & Human & ctx $\mathrm{A}$, zot, ace, tcp $\mathrm{A}$ \\
\hline 2494 & $\mathrm{O} 26$ & Environment & ctx $\mathrm{A}$, zot, ace, tcp $\mathrm{A}$ \\
\hline 13653 & $\mathrm{O} 27$ & Human & - - \\
\hline 13488 & O34 & Human & - - \\
\hline 4482 & $\mathrm{O} 37$ & Human & zot, ace \\
\hline 13154,16580 & O37 & Human & - \\
\hline 14831 & $\mathrm{O} 45$ & Human & tcp $\mathrm{A}$ \\
\hline 14813 & $\mathrm{O} 45$ & Human & - - \\
\hline 13662 & O51 & Human & zot \\
\hline 3833 & O51 & Environment & zot, ace, tcp $\mathrm{A}$ \\
\hline 14833 & O56 & Human & - - \\
\hline 7098 & O94 & Human & zot \\
\hline 15381 & Rough strain & Human & - - \\
\hline 17155 & Not typable & Human & $c t x \mathrm{~A}$, zot, ace, tcp $\mathrm{A}$ \\
\hline
\end{tabular}

were performed in $25 \mu \mathrm{L}$ volume containing $2.5 \mu \mathrm{L}$ of $10 \mathrm{x}$ reaction buffer, $200 \mu \mathrm{M}$ each of dNTP, 20 pmol of primer, $3 \mathrm{mM}$ of $\mathrm{MgCl}_{2}, 2 \mathrm{U}$ of Taq DNA polymerase and $20 \mathrm{ng}$ of genomic DNA under a drop of mineral oil.

The PCR reaction was performed on 30 cycles: $94{ }^{\circ} \mathrm{C}$ for one min, $36^{\circ} \mathrm{C}$ for one min, $72{ }^{\circ} \mathrm{C}$ for $1.5 \mathrm{~min}$, and than kept at $72^{\circ} \mathrm{C}$ for $10 \mathrm{~min}$. A non-template control was included in each RAPD-PCR run. The PCR amplification products were separated by electrophoresis on $1.5 \%$ agarose gels and visualized after staining with ethidium bromide.

\section{RESULTS}

The serogrouping results are shown in Table 2. None of the $179 \mathrm{~V}$. cholerae isolates agglutinated with antisera to $\mathrm{O} 1$ or $\mathrm{O} 139$, but 173 of them $(96.6 \%)$ could be divided in 54 different serogroups, with O26 (7.8\%) and $\mathrm{O} 37(7.3 \%)$ being the most prevalent.

Of the 179 isolates, 27 strains harbored one or more of the virulenceassociated genes (Table 4). Eight (4.5\%) strains were ctxA gene positive being observed only in $V$. cholerae $\mathrm{O} 26$. All the $V$. cholerae $\mathrm{O} 26$ strains, without exception, were positive for one or more virulence-associated encoding genes. The $c t x \mathrm{~A}$ gene was not present independent of the zot and ace genes, but zot gene was found to be distributed in 19 strains of $V$. cholerae non-O1/non-O139 (17 clinical and two environmental) in the absence of the $c t x \mathrm{~A}$ and/or ace genes. The tcpA gene was present in eight strains of the $V$. cholerae non-O1/non-O139, which contained one or more gene of the CTX genetic element. However, this gene was also present in one isolate (strain 14831) negative for all genes of the CTX element studied. Furthermore, five clinical strains that were positive for $c t x \mathrm{~A}$, were negative for $t c p \mathrm{~A}$.

The genetic relatedness of the clinical and environmental $V$. cholerae non-O1/non-O139 strains was investigated by RAPD-PCR. Three primers were selected in this study and the primer 785 generated the best amplification patterns for differentiation of $V$. cholerae strains belonging to the serogroups $\mathrm{O} 6, \mathrm{O} 7, \mathrm{O} 8, \mathrm{O} 10, \mathrm{O} 14, \mathrm{O} 17, \mathrm{O} 27, \mathrm{O} 28$, O34, O37, O45, O51, O56 and O94. A second profile was built with all 13 clinical and one environmental isolates of $V$. cholerae $\mathrm{O} 26$.

The RAPD-PCR with primer 785 with $V$. cholerae non-O1/nonO139 strains produced different fingerprints into the same serogroup: O6 (IOC 3874, 3905); O10 (IOC15251, 15380); O37 (IOC 4482, 13154, 16580 ) and most of the $V$. cholerae $\mathrm{O} 26$ strains. However, identical RAPD profiles were observed in the $V$. cholerae O6 (IOC 157, 3874); O26 (IOC 13151, 2494) and O45 (IOC 14813, 14831).

\section{DISCUSSION}

To date, ca. 200 serogroups of $V$. cholerae have been recorded, and two (O1 and O139) have been associated with major cholera epidemics. The other serogroups, referred as non-O1/non-O139, have not been associated with epidemics rather can cause sporadic diarrhea and occasionally outbreaks ${ }^{30}$. This outline distinction between serogroups is related to the observation that more than $95 \%$ of the strains belonging to serogroups $\mathrm{O} 1$ and $\mathrm{O} 139$ produce cholera toxin $(\mathrm{CT})^{15}$. In contrast, more than $95 \%$ of the strains belonging to non-O1/non-O139 serogroups do not produce $\mathrm{CT}$ or $\mathrm{TCP}^{25}$. The detection of $\operatorname{ctx} \mathrm{A}$ gene in only $4.5 \%$ of the strains in this study, is in agreement with the toxigenic profile of the $V$. cholerae. However, our results contradict the assumption that most cholera toxin-producing strains are also positive for TCP, since TCP is known to be the receptor for CTX $\phi$ infection of $V$. cholerae. In fact, our results appear to be consistent with data from recent studies that report the presence of the two virulence genes found in epidemic strains, $c t x \mathrm{AB}$ and $t c p \mathrm{~A}$, in environmental and clinical strain of serogroups other than $\mathrm{O} 1$ and $\mathrm{O} 139^{5,10,27,28,31,32}$.

It has been suggested that most $V$. cholerae strains, especially those from the environment, lack the genes required to produce CT and the possibility of genetic exchange in the environment allows the potential emergence of new toxigenic clones. This mechanism of horizontal gene transfer plays an important role increasing the genetic variability of a bacterial species and also confers new phenotypes, such as virulence, to the recipient. The emergence of new toxigenic strains of $V$. cholerae and their selective enrichment during cholera outbreaks constitute essential mechanisms for the survival and evolution of $V$. cholerae and the genetic elements that mediate the transfer of virulence genes ${ }^{11}$.

The ctx $\mathrm{AB}$ genes are carried in the genome of a lysogenic filamentous bacteriophage designated $\mathrm{CTX}^{36}$ and their dissemination 


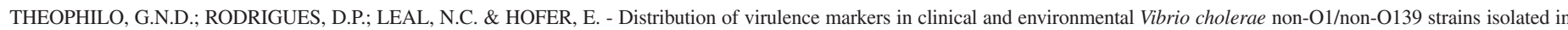
Brazil from 1991 to 2000. Rev. Inst. Med. trop. S. Paulo, 48(2):65-70, 2006.

Table 4

Distribution of virulence genes in clinical and environmental of different serogroups of Vibrio cholerae non-O1/non-O139

\begin{tabular}{|c|c|c|c|c|c|c|c|}
\hline \multirow[t]{2}{*}{ Isolate No. IOC/Year } & \multirow[t]{2}{*}{ Origin } & \multirow[t]{2}{*}{ Source } & \multirow[t]{2}{*}{ Serogroup } & \multicolumn{4}{|c|}{ Presence of virulence genes } \\
\hline & & & & $\operatorname{ctxA}$ & zot & ace & $t c p \mathrm{~A}$ \\
\hline $157 / 91$ & Amazonas & Human & O6 & & + & & \\
\hline $3874 / 92$ & Paraíba & Human & O6 & & + & & \\
\hline $3905 / 92$ & Pernambuco & Human & O6 & & + & & \\
\hline $13153 / 94$ & Pernambuco & Human & $\mathrm{O} 7$ & & + & + & \\
\hline $4005 / 92$ & Pernambuco & Human & $\mathrm{O} 10$ & & + & & \\
\hline $2556 / 92$ & Paraíba & Human & O17 & & + & + & \\
\hline $1717 / 92$ & Pernambuco & Human & $\mathrm{O} 26$ & & + & + & \\
\hline $3340 / 92$ & Pernambuco & Human & $\mathrm{O} 26$ & + & + & + & \\
\hline $3647 / 92$ & Pernambuco & Human & $\mathrm{O} 26$ & & + & & \\
\hline $4010 / 92$ & Pernambuco & Human & $\mathrm{O} 26$ & + & + & + & + \\
\hline $4756 / 92$ & Pernambuco & Human & $\mathrm{O} 26$ & + & + & + & \\
\hline $6958 / 92$ & Ceará & Human & $\mathrm{O} 26$ & + & + & + & \\
\hline $10626 / 93$ & Bahia & Human & $\mathrm{O} 26$ & & + & + & \\
\hline $11043 / 93$ & Pernambuco & Human & $\mathrm{O} 26$ & & + & + & + \\
\hline $11159 / 93$ & Pernambuco & Human & $\mathrm{O} 26$ & + & + & + & \\
\hline $13151 / 94$ & Pernambuco & Human & $\mathrm{O} 26$ & + & + & + & \\
\hline $13663 / 94$ & Pernambuco & Human & $\mathrm{O} 26$ & & + & + & + \\
\hline $15677 / 98$ & Ceará & Human & $\mathrm{O} 26$ & & + & + & + \\
\hline $16352 / 99$ & Ceará & Human & $\mathrm{O} 26$ & & + & & \\
\hline $2494 / 92$ & Bahia & Environment & $\mathrm{O} 26$ & + & + & + & + \\
\hline $16360 / 99$ & Ceará & Environment & $\mathrm{O} 28$ & & + & + & + \\
\hline $4482 / 92$ & Pernambuco & Human & O37 & & + & + & \\
\hline $14831 / 95$ & Ceará & Human & $\mathrm{O} 45$ & & & & + \\
\hline $13662 / 94$ & Pernambuco & Human & O51 & & + & & \\
\hline $3833 / 92$ & Paraíba & Environment & O51 & & + & + & + \\
\hline $7098 / 92$ & Amazonas & Human & O94 & & + & & \\
\hline $17155 / 00$ & Pernambuco & Human & NT & + & + & + & + \\
\hline
\end{tabular}

IOC = Instituto Oswaldo Cruz, NT = Not typable strain.

to non-pathogenic strains may occur via phage-mediated horizontal gene transfer. The pilus colonization factor (TCP) is also known to act as a receptor for CTX $\phi$ and is itself encoded by a recently described novel lysogenic bacteriophage, VPI $\phi^{17}$. Hence, we presumed that only non-toxigenic $V$. cholerae strains that already contain TCP can acquire $c t x \mathrm{AB}$ via lysogenic conversion by CTX $\phi$ infection. However, in our findings five human strains were $c t x \mathrm{~A}^{+} / t c p \mathrm{~A}^{-}$(Table 4). Some authors have suggested that such isolates arose by TCP-mediated CTX $\phi$ infection, with subsequent loss of the TCP island (VPI $\phi)^{11}$. Alternatively, such strains may possess an as-yet-unidentified receptor and/or modes of CTX $\phi$ acquisition that account for the presence of a CTX $\phi$ prophage in these strains ${ }^{12}$. In our study the non-toxigenic strain positive for tcpA (IOC 14831-Table 3) may be a potential precursor of toxigenic strains because of its dual capacity to serve as efficient recipient of CTX phage and to colonize the human intestine by TCP-dependent mechanisms. Moreover, were identified eighteen $V$. cholerae non-O1/ non-O139 strains (10\%) that contained zot and/or ace but lacked ctxA. This finding is somewhat unexpected since the three genes are part of the CTX genetic element. However, similar results were obtained by VITAL BRAZIL et al. ${ }^{35}$, which analyzed the prevalence of virulenceassociated genes in $V$. cholerae strains isolated in Brazil and showed that 31 strains $(8.3 \%)$ did not contain $\operatorname{ctxA}$. Thus, we hypothesized that there was lost ctxA later integration of CTX $\phi$ DNA into the $V$. cholerae chromosome.

In previous study was observed that when the RAPD reactions are performed under rigorous reaction conditions (same preparation of genomic DNA, brand and lot of enzyme), the pattern of bands is reproducible $^{21}$. In this study, standardized RAPD method showed to be reproductive and ascertained the diversity of the serogroups of the $V$. cholerae analyzed, which was demonstrated by the presence of different subtypes into the same serogroup.

Identification of the non-O1/non-O139 serogroups of $V$. cholerae carrying virulence genes is very important since these new toxigenic strains with epidemic potential may emerge in the future. This finding is based first on the emergence of serogroup O139 (Bengal) in Bangladesh (CT positive) and Argentina (CT negative), each of which clearly evolved independently ${ }^{33}$. Second, the isolates from the sixth and seventh pandemic, and U.S. Gulf Coast belong to three different clones, each independently, evolved from environmental non-O1 $\mathrm{V}$. cholerae isolates ${ }^{16}$. Third, the high relatedness of different serogroups of $V$. cholerae strains isolated in Brazil ${ }^{34}$, and other epidemic serogroups have emerged, including $V$. cholerae $\mathrm{O} 10^{13}, \mathrm{O} 12^{9}, \mathrm{O}_{2} 2^{14}, \mathrm{O} 31^{26}, \mathrm{O}_{3} 7^{8}$, 


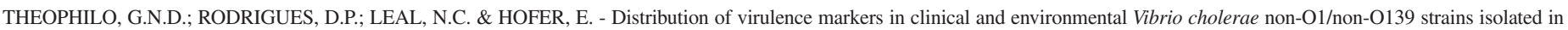
Brazil from 1991 to 2000. Rev. Inst. Med. trop. S. Paulo, 48(2):65-70, 2006.

and $\mathrm{O} 141^{10}$. These findings stress the need for continued surveillance of non-O1/non-O139 V. cholerae.

\section{RESUMO}

\section{Distribuição dos marcadores de virulência em cepas clínicas e ambientais de Vibrio cholerae não 01/não 0139, isoladas no Brasil no período de 1991 a 2000}

Cento e setenta e nove amostras de $V$. cholerae não $\mathrm{O} 1 /$ não $\mathrm{O} 139$, isoladas de casos clínicos (139) e de meio ambiente (40), no período de 1991 a 2000 no Brasil, foram caracterizadas antigenicamente pelo National Institute of Health (Japão) e investigadas quanto ao seu potencial genético de virulência, representado pelos genes $\operatorname{ctx} \mathrm{A}$, zot, ace e tcpA. As análises fenotípicas revelaram extraordinária diversidade antigênica, com a ocorrência de 54 diferentes sorogrupos, com prevalência para $\mathrm{O} 26(7,8 \%)$. A técnica de PCR, empregada na detecção dos genes localizados no elemento genético CTX $(\operatorname{ctxA}$, zot, ace $)$ e na Ilha de Patogenicidade de Vibrio-VPI (tcpA), possibilitou a identificação de 27 cepas contendo qualquer um desses genes. O gene ctxA (codificador da sub-unidade A de CT), só foi evidenciado no sorogrupo O26, sendo também o único capaz de se apresentar com o cassete de virulência de forma intacta. Com base nos resultados obtidos deste estudo preliminar, admite-se a hipótese da potencialidade destas cepas, evoluir para raças epidêmicas.

\section{ACKNOWLEDGMENTS}

The authors thank the staff of the National Institute of Health, Tokyo, Japan for their technical support in the characterization of serogroup of non-O1 Vibrio cholerae and Mr. Evaldo Soares da Silva, Mr. Elcio Onofre da Silva, Mr. Junair Ribeiro for technical assistance. This work was partially supported by grants from CNPq (National Council for Research Support -Brazil) - Proc . 521270/96-0 (NV).

\section{REFERENCES}

1. ALBERT, M.J.; SIDDIQUE, A.K.; ISLAM, M.S. et al. - Large outbreak of clinical cholera due to Vibrio cholerae non-O1 in Bangladesh. Lancet, 341: 704, 1993.

2. AUSUBEL, F.M.; BRENT, R.; KINGSTON, R.E. et al. - Current protocol in molecular biology. New York, Wiley, 1987.

3. BAUDRY, B.; FASANO, A.; KETLEY, J. \& KAPER, J. - Cloning of gene (zot) encoding a new toxin produced by Vibrio cholerae. Infect. Immun., 60: 428-434, 1992.

4. BOYD, E.F.; MOYER, K.E.; SHI, L. \& WALDOR, M.K. - Infectious CTX Phi and the vibrio pathogenicity island prophage in Vibrio mimicus: evidence for recent horizontal transfer between V. mimicus and V. cholerae. Infect. Immun., 68: 1507-1513, 2000.

5. BOYD, E.F. \& WALDOR, M.K. - Evolutionary and functional analyses of variants of the toxin-coregulated pilus protein TcpA from toxigenic Vibrio cholerae non-O1/ non-O139 serogroup isolates. Microbiology, 148: 1655-1666, 2002.

6. COLOMBO, M.M.; MASTRANDREA, S.; SANTONA, A. et al. - Distribution of the ace, zot, and $\operatorname{ctx} \mathrm{A}$ toxin genes in clinical and environmental Vibrio cholerae. J. infect. Dis., 170: 750-751, 1994.

7. COLWELL, R.R. - Global climate and infectious disease: the cholera paradigm. Science, 274: 2025-2031, 1996.
8. DAKIN, W.P.H.; HOWEL, D.J; SUTTON, R.G.A.; O'KEEFE, M.E. \& THOMAS, P. Gastroenteritis due to non-agglutinable (non-cholera) vibrios. Med. J. Aust., 2: 487490, 1974.

9. DALSGAARD, A.; ALBERT, M.J.; TAYLOR, D.N. et al. - Characterization of Vibrio cholerae non-O1 serogroups obtained from outbreak of diarrhea in Lima, Peru. J. clin. Microbiol., 33: 2715-2722, 1995.

10. DALSGAARD, A.; SERICHANTALERGS, O.; FORSLUND, A. et al. - Multiple clinical and environmental isolates of Vibrio cholerae serogroup O141 carry the ctx phage and the genes encoding the toxin coregulated pili. J. clin. Microbiol., 39: 40864092, 2001

11. FARUQUE, S.M.; ALBERT, M.J. \& MEKALANOS, J.J. - Epidemiology, genetics, and ecology of toxigenic Vibrio cholerae. Microbiol. molec. Biol. Rev., 62: 1301-1314, 1998.

12. FARUQUE, S.M.; RAHMAN, M.M.; ASADULGHANI, K.M.; ISLAM, N. \& MEKALANOS, J.J. - Lysogenic conversion of environmental Vibrio mimicus strains by CTX Phi. Infect. Immun., 67: 5723-5729, 1999.

13. HOFER, E. - Vibrio cholerae não $\mathrm{O} 1$ associado à infecção entérica humana no Estado da Bahia, Brasil. Rev. Microbiol. (S. Paulo), 18: 1-4, 1987.

14. HOFER, E.; REIS, E.M.F.; QUINTAES, B.R. et al. - Vibrio cholerae resistant to 2,4 diamimo-6,7-diisopropylpteridine $(\mathrm{O} / 129)$ isolated from patients with enteritis in Ceará, Brazil. J. HIth Popul. Nutr., 19: 39-42, 2001.

15. KAPER, J.B.; MORRIS Jr., J.G. \& LEVINE, M.M. - Cholera. Clin. Microbiol. Rev., 8: 48-86, 1995.

16. KARAOLIS, D.K.; LAN, R. \& REEVES, P.R. - The sixth and seventh cholera pandemics are due to independent clones separately derived from environmental, non-toxigenic, non-O1 Vibrio cholerae. J. Bact., 177: 3191-3198, 1995.

17. KARAOLIS, D.K.; SOMARA, S.; MANEVAL Jr., D.R.; JOHNSON, J.A. \& KAPER, J.B. - A bacteriophage encoding a pathogenicity island, a type-IV pilus and a phage receptor in cholera bacteria. Nature, 399: 375-379, 1999.

18. KARASAWA, T.; MIHARA, T.; KURAZONO, H. et al. - Distribution of the zot (zonula occludens toxin) gene among strains of Vibrio cholerae O1 and non O1. Microbiol. Lett., 106: 143-146, 1993

19. KEASLER, S.P. \& HALL, R.H. - Detecting and biotyping Vibrio cholerae O1 with multiplex polymerase chain reaction. Lancet, 341: 1661, 1993.

20. KURAZONO, H.; PAL, A.; BAG, P.K. et al. - Distribution of genes encoding cholera toxin, zonula occludens toxin, accessory cholera toxin and El Tor hemolysin in Vibrio cholerae of diverse origins. Microb. Pathog., 18: 231-235, 1995.

21. LEAL, N.C.; SOBREIRA, M.; LEAL-BALBINO, T.C. et al. - Evaluation of RAPDbased typing scheme in a molecular epidemiology study of Vibrio cholerae O1, Brazil. J. appl. Microbiol., 96: 447-454, 2004

22. MEKALANOS, J.J. - Duplication and amplification of toxin genes in Vibrio cholerae. Cell, 35: 253-263, 1983.

23. Ministério da Saúde - Manual de diagnóstico laboratorial. Brasília, Comissão Nacional de Prevenção da Cólera (CNPC), 1992. p. 13-26.

24. MORRIS Jr., J.G. - Non-O group 1 Vibrio cholerae: a look at the epidemiology of an occasional pathogen. Epidem. Rev., 12: 179-191, 1990.

25. MORRIS Jr., J.G. - Non-O1 group 1 Vibrio cholerae strains not associated with epidemic disease. In: WACHSMUTH, I.K.; BLAKE, P.A. \& ØLSVIK, O., ed. Vibrio cholerae and cholera: molecular to global perspectives. Washington, ASM Press, 1994. p. 103-115. 


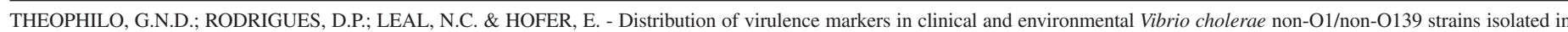
Brazil from 1991 to 2000. Rev. Inst. Med. trop. S. Paulo, 48(2):65-70, 2006.

26. MORRIS Jr., J.G.; TAKEDA, T; TALL, B.D. et al. - Experimental non-O group 1 Vibrio cholerae gastroenteritis in humans. J. clin. Invest., 85: 697-705,1990.

27. MUKHOPADHYAY, A.K.; CHAKRABORTY, S.; TAKEDA, Y.; NAIR, G.B. \& BERG, D.E. - Characterization of VPI pathogenicity island and CTX phi prophage in environmental strains of Vibrio cholerae. J. Bact., 183: 4737-4746, 2001.

28. NOVAIS, R.C.; COELHO, A.; SALLES, C.A. \& VICENTE, A.C.P. - Toxin-co-regulated pilus cluster in non-O1, non-toxigenic Vibrio cholerae: evidence of a third allele of pilin gene. FEMS Microbiol. Lett., 171: 49-55, 1999.

29. OLSVIK, O.; POPOVIC, T. \& FIELDS, P.I. - PCR detection of toxin on strains of Vibrio cholerae O1. In: PERSING, D.H.; SMITH, T.F.; TENOVER, F.C. \& WHITE, T.J., ed. Diagnostic molecular microbiology: principles and applications. Washington, ASM Press, 1993. p. 266-270.

30. RAMAMURTHY, T.; BAG, P.K.; PAL, A. et al. - Virulence patterns of Vibrio cholerae non-O1 strains isolated from hospitalized patients with acute diarrhoea in Calcutta, India. J. med. Microbiol., 39: 310-317, 1993.

31. SAID, B.; SMITH, H.R.; SCOTLAND, S.M. \& ROWE, B. - Detection and differentiation of the gene for toxin co-regulated pili (tcpA) in Vibrio cholerae non-O1 using the polymerase chain reaction. FEMS Microbiol. Lett., 125: 205-210, 1995.
32. SINGH, D.V.; MATTE, M.H.; MATTE, G.R. et al. - Molecular analysis of Vibrio cholerae O1, O139, non-O1, and non-O139 strains: clonal relationship between clinical and environmental isolates. Appl. environ. Microbiol., 67: 910-921, 2001.

33. STROEHER, U.H.; JEDANI, K.E.; DREDGE, B.K. et al. - Genetic rearrangements in the $r f b$ regions of Vibrio cholerae O1 and O139. Proc. nat. Acad. Sci. (Wash.), 92: 10374-10378, 1995.

34. THOMPSON, F.L.; THOMPSON, C.C.; VICENTE, A.C.P. et al. - Genomic diversity of clinical and environmental Vibrio cholerae strains isolated in Brazil between 1991 and 2001 as revealed by fluorescent amplified fragment length polimorphism analysis. J. clin. Microbiol., 41: 1946-1950, 2003.

35. VITAL BRAZIL, J.M.; ALVES, R.M.; RIVERA, I.N. et al. - Prevalence of virulenceassociated genes in clinical and environmental Vibrio cholerae strains isolated in Brazil between 1991 and 1999. FEMS Microbiol. Lett., 215: 15-21, 2002.

36. WALDOR, M.K. \& MEKALANOS, J.J. - Lysogenic conversion by a filamentous phage encoding cholera toxin. Science, 272: 1910-1914, 1996.

37. YAMAI, S.; OKITSU, T.; SHIMADA, T. \& KATSUBE, Y. - Distribution of serogroups of Vibrio cholerae non-O1/non-O139 with specific reference to their ability to produce cholera toxin, and addition of novel serogroups. J. Jap. Ass. infect. Dis., 71: 1037 1045, 1997.

Received: 10 June 2005

Accepted: 29 November 2005 